\title{
Effectiveness of health education intervention on foot self-care practice among diabetics at Zagazig university hospitals
}

\author{
Noha M. Abdelsalam ${ }^{1}$, Huny M. Bakry ${ }^{1}$, Randa M. said ${ }^{2}$, Marwa A. Hammad ${ }^{3}$, Amel \\ E. Mohamed ${ }^{1}$, Arafa M. El Shabrawy ${ }^{4}$ \\ ${ }^{1}$ Public Health and Preventive Medicine Deparrtment, ${ }^{2}$ Family Medicine, ${ }^{3}$ Rheumatology \\ and Rehabilitation Department, ${ }^{4}$ Internal medicine Department (endocrinology unit) \\ Faculty of Medicine, Zagazig University, Egypt
}

\begin{abstract}
Background: Diabetic patients are at risk for developing diabetic foot problems as infection, ulcer and gangrene which are the most common cause of hospitalization among diabetics. Proper foot care is very necessary for preventing these problems and improving quality of life of these patients. Aim the aim of this study was to assess the effectiveness of health education intervention on self-care knowledge and foot care practice among diabetic patients. Methods: an intervention field trial was conducted on 76 diabetic patients attending Zagazig University Hospital outpatient clinics using structured questionnaire for self-care knowledge assessment and structured questionnaire guided by American diabetes association guidelines for foot care practice assessment. The International Working Group on the Diabetic Foot (IWGDF) -Risk Classification System was used for risk classification of the studied diabetic patients. Results $31.5 \%$ of studied patients had high risk for diabetic foot. There was significant improvement in the total knowledge score from $8.17 \pm 2.4$ to $16.16 \pm 2.3$ after application of the intervention. Also there was significant improvement in the total practice score ( $\mathrm{p}$ value $<0.001$ ). Recommendation: Targeted health education programs regarding foot care strategies for diabetic patients are needed to reduce diabetic foot complications and ultimately amputation.
\end{abstract}

Key words: Diabetics, foot practice, Self-care, Knowledge, Health education.

Corresponding author: Noha M. Abdelsalam Email: Noha_Mohamed994@yahoo.com

\section{Introduction}

Diabetes is a chronic complex disease that requires continuous care, proper control and multifactorial strategies for risk reduction ${ }^{1}$. Diabetes can cause number of severe complications that increase morbidity, mortality and health care cost ${ }^{2}$.

Diabetic foot problems are one of the most common chronic complications of diabetes that has a tremendous economic and social impact on individuals, families and on health system as a whole in developing and developed countries ${ }^{3}$. Improper foot care in diabetic patients can lead to many complications such as infection, ulcerations, gangrene and amputations ${ }^{4}$. The prevalence of diabetic foot ulcers has been found to be high in Egypt, it is estimated from a recent study conducted among diabetics in Egypt, that (29.3\%) of diabetics had foot ulcer disease; $(63.3 \%)$ had vascular complications, and neuropathy was reported in $(88.0 \%)$ of them ${ }^{5}$. Diabetic foot complications were attributed to the lack of knowledge about foot care among diabetic patients and the feet improper wear ${ }^{6}$ Diabetic foot problems can be prevented through well-coordinated foot care services. Patient education is an important and essential element of any health program for diabetic foot prevention and control ${ }^{3,7}$. When patients have sufficient knowledge about their 
disease, they are more likely to adhere to their treatment regimen. Foot care knowledge and behavior of patients are influenced positively by their information about their medical condition $^{8-10}$.

The practice of diabetic foot care includes daily foot examination, use of appropriate footwear to prevent foot ulcers development, Check of water temperature before bath and seek professional help for any problem ${ }^{10}$.

Since studies showed that more than $90 \%$ of the people having diabetes in Egypt do not receive education on diabetic foot problems and care $^{6}$, we aimed in this study to improve the quality of life of diabetic patients attending outpatient clinic at Zagazig University Hospitals through improving their foot self-care practices.

The aim of the present study is to identify risk of having diabetic foot among the studied patients, to assess the current foot self-care knowledge level foot care practice among diabetic patients, to implement health education intervention and to evaluate the effectiveness of intervention regarding foot self-care knowledge and foot care practice among our participants.

\section{Methods}

Study design and setting: An interventional field trial in the diabetic foot outpatient clinic at Zagazig University Hospitals was conducted over a period of 10 months (from January 2015 till October 2015) through three phases:

Assessment phase was conducted over a period of two months to assess the selfcare knowledge and foot care practice. Also the risk of developing diabetic foot was assessed.

Implementation phase was conducted over a period of three months in which educational sessions and small group discussions were held based on the
American diabetes association guidelines regarding foot care practice.

Evaluation phase was conducted over a period of two months to evaluate the measurable outcome through reassessment of self-care knowledge and foot care practice. This phase was started three months after the implementation phase.

Sample size and sampling: Sample size was calculated to be 76 participants using Epi software version 6 after conduction of a pilot study which revealed improvement in knowledge after health education by $32 \%$ (from $28 \%$ to $60 \%$ ) at confidence interval $95 \%$. Our participants were selected by systematic random sample from follow up records of diabetic foot outpatient clinic.

Data collection tools: A structured questionnaire to assess the foot self-care knowledge of the participants. It was used as pre and post tests. It is divided into three parts. The 1st part included personal data. The 2nd part included diabetic history. The 3rd part included 18 multiple choice questions assessing foot self-care knowledge. In the knowledge section, each correct answer took 1 degree and incorrect answer took zero. Total score was 18 degrees. Knowledge was considered poor if $(\leq 50 \%)$ of total score and good if $(>50 \%)$ of total score. A structured questionnaire to assess the foot care Practice of the participants guided by the guidelines of American diabetes association for foot care practice (11). It was filled before and after intervention. It included 12 items; feet inspection, shoes inspection before putting on, washing feet with warm water, drying feet after washing, using emollients for dry skin, cutting toenails properly, walking bare foot, wearing shoes without socks, check between toes, drying between toes, check of water temperature before bath and seek professional help for any problem. Answers were presented as (yes, no) with scores (zero. one respectively except in 2 
items (walking bare foot, wearing shoes without socks) the scoring was reversed. Total score was 12 degrees. Practice was considered poor if $(\leq 50 \%)$ of total score and Good if $(>50 \%)$ of total score. A Comprehensive foot examination was done to cover Key components of the diabetic foot exam (dermatological, musculoskeletal, neurological and vascular assessment .The International Working Group on the Diabetic Foot (IWGDF) -Risk Classification System was used for risk classification of the studied diabetic patients. Once the patient had been assessed clinically, he or she was assigned to a foot risk category. (0 Normal- no neuropathy, 1 Loss of protective sensation (LOPS), 2a LOPS and deformity, 2b Peripheral arterial disease, 3a Previous history of ulceration, $3 \mathrm{~b}$ Previous history of amputation) .These categories were designed to direct referral and subsequent therapy by the specialty clinician or team and frequency of follow-up by the generalist or specialist. Increased category is associated with an increased risk for ulceration, hospitalization, and amputation .Patients in risk category 0 generally do not need referral and should receive general foot care education and undergo comprehensive foot examination annually. Patients in foot risk category 1 may be managed by a generalist or specialist every 3-6 months. Consideration should be given to an initial specialist referral to assess the need for specialized treatment and follow-up. Those in categories 2 and 3 should be referred to a foot care specialist or specialty clinic and seen every $1-3$ months ${ }^{12}$.

Experimental tools: Colored brochures, booklets, Videos and power point presentations about care of diabetic feet were used in the health education sessions (4 sessions, each session last for one hour) to improve the awareness and behavior of the participants.

Statistical management:

The Egyptian Journal of Community Medicine
After data collection, data were coded, entered and analyzed using SPSS (Statistical Package for Social Science) version 19. Chi-square and McNemar test was used for comparing descriptive data and paired $\mathrm{t}$ test and Wilcoxon Signed Rank Test was used for comparing quantitative data. $\mathrm{P}$ value $(\leq$ $0.05)$ was considered significant difference and $\mathrm{P}$ value $(\leq 0.01)$ was considered highly significant difference.

Ethical aspect and administrative approach: Before carrying out the study, the necessary official permission was taken from the head of Internal Medicine department and the head of Zagazig University Hospitals. An informed verbal consent was obtained from patients and they were reassured about the confidentiality of any obtained information and that the results would be used for the purpose of research.

\section{Results}

Table 1 shows that the mean age of participants was $55.0 \pm 10.1$. Male: female ratio was nearly $1: 1$. Most of participant were residents of rural areas and only $15.7 \%$ of them were of higher education. More than half of them were not working, but most of them had sufficient income (income satisfy needs).

Table 2 shows that majority of participant are suffering from type 2 diabetes with median duration 10 years, More than half of them receive oral hypoglycemic therapy. Only $7.0 \%$ of them had a history of foot ulcer and no history of amputation. More than half of them had eye and neurological complications. Most of participants regularly monitor their blood sugar level every month (known from records). $36.8 \%$ of them said that they had advice on foot care from their physicians and $28.9 \%$ of them reported that they care for their foot.

Table 3 show that $31.5 \%$ of studied patients had high risk for diabetic foot (Loss of protective sensation and

$\begin{array}{llll}\text { Vol. } 35 & \text { No. } 4 & \text { October } & 2017\end{array}$


deformity, peripheral arterial disease and past history of ulceration), while $39.5 \%$ of them were normal with no peripheral neuropathy (low risk).

Table 4 shows that there was significant improvement of all items of knowledge with a significant improvement in the knowledge total score of the studied sample from $8.17 \pm 2.4$ in the pretest to $16.16 \pm 2.3$ in the post test.

Table 5 shows that there is significant improvement of self-care practice items except for drying between toes with significant improvement in the practice total score ( $\mathrm{p}$ value $<0.001$ ).

Table 6 shows that sex, residence and education had significant effect on knowledge of the participants as males, and residents of urban areas and highly educated participants had good knowledge. Also practice was significantly better among females and residents of urban areas, while occupation and education had no significant effect on knowledge and practice of participants.

\section{Discussion:}

People with diabetes are prone to develop foot ulcer, amputation and other lower extremity clinical abnormalities if they do not have good knowledge of foot care practice $^{13}$. Our study was an intervention field trial conducted upon 76 diabetic patients to improve their knowledge about diabetic foot and their foot care practice.

This study showed that $7.9 \%$ of studied diabetics had previous history of foot ulcers This finding with in accordance with studies conducted by Ogbera et $\mathrm{al}^{14}$ and Prompers et $\mathrm{al}^{15}$ that stated that the prevalence of foot ulcers is approximately 4-20\% in diabetes patients in their reports. However in Ren et $\mathrm{al}^{16}, 15.7 \%$ of diabetes patients at high risk of diabetic foot had a foot ulceration history, this percentage was lower than that percentage reported in our study which was $(25.0 \%)$ of diabetes patients at high risk (6 out of 24 high risk patients)

Foot care knowledge: Our results showed that the baseline knowledge of the majority of our participants was unsatisfactory; this finding was in accordance with studies conducted in Malaysia ${ }^{17}$ and Nigeria ${ }^{13}$ which reported poor knowledge among their studied sample. Also we found that being a females of low education had a significant effect on the level of knowledge, which was contrary to another study reported that there was no significant association between patients' demographics with the level of knowledge diabetic foot care ${ }^{13}$.

Our findings were in accordance with a study conducted in Pakistan ${ }^{18}$ and Desalu et $\mathrm{al}^{13}$ who stated the significance association of low level of education and poor knowledge about diabetic foot practice. Our findings were confirmed by the fact that $97 \%$ of females above forty in rural Egypt are illiterate ${ }^{19}$ and that Education improves an individual's cognitive skills, including reading and information processing ${ }^{20}$. Consequently, the higher educated are more likely to use health information resources ${ }^{21,22}$.

Our results revealed significant improvement in the knowledge of our participants after application of the health education intervention and this was in accordance with other studies conducted in Washington ${ }^{23}$ and Tanzania ${ }^{24}$ where the latest recommended provision of continuous foot care education to patients and health care providers through coordinated foot care services within the diabetic clinic.

Diabetic Foot care Practice: Our findings revealed poor baseline practice in the majority of our studied group which was confirmed by the results of other Malaysian study ${ }^{17}$. Also, our results showed that low level of education had a significant effect on the baseline practice which was in line with a similar study 
reported the significance effect of education on the level of practice ${ }^{13}$.

Our results revealed that being a female had significant effect on the level of practice which was contrary to another study conducted in Lahore which reported no significant association between sex and diabetic foot practice ${ }^{25}$. Our findings were contrary to the culture of rural Egyptian women as Egyptian women's behaviors were known to be strongly influenced by their husbands and mothers-in-law after marriage ${ }^{26,27}$ which may be a cause that they put their health of low priority due to increased daily family duties. After health education intervention most items of foot care practice was significantly improved and this was in accordance with a study conducted in a primary care center which reported improvement of foot care practice after their education ${ }^{28}$. We attributed our finding that the content of the educational program and the group discussions of the participants with the

\section{References:}

1. American Diabetes Association (2015): The standards of medical care in diabetes. Diabetes Care; 38 (Suppl. 1):S1-S2.

2. American Diabetes Association (2013): Economic costs of diabetes in the U.S. in 2012. Diabetes Care. 36:103346.

3. Saleh N, Shebl A, Hatata E, and Refiei M (2012): impact of Educational Program about Foot Care on Knowledge and Self Care Practice for Diabetic Older Adult.2012. Journal of American Science; 8(12).Available at http://www.jofamericanscience.org.

4. Freeman D (2002): Corns and calluses resulting from mechanical hyperkeratosis. Am Fam Physician; 65: 2277-80.

5. Al-Ghazaly G, Al-Ahwal L and Zagloul K( 2015): Risk factors of diabetic foot ulcer in patients attending diabetic foot outpatient clinic at Tanta researchers helped to increase the selfefficacy of the participants which had a great effect on the practice. We attributed our finding that the content of the educational program and the group discussions of the participants with the researchers helped to increase the selfefficacy of the participants which had a great effect on the practice.

\section{Conclusion and Recommendation}

This study showed poor diabetic foot care knowledge and practice. Health education intervention succeeded in improving them which suggest the need of targeted training programs for health care providers at the primary level about the importance of regular foot examination, risk assessment and foot education are needed to decrease the burden of complication and increase the wellbeing of diabetic patients.

University Hospital in Egypt. The Journal of Diabetic Foot Complications, 2015; Volume 7, Issue 2, No. 3, Pages 42-48.

6. Gawish H (2012): Preventive foot care, Egypt. Available at http://www.google.com/ retrieved March 2012.

7. Gondal M, Bano U, Moin S, et al (2007): Evaluation of knowledge and practices of foot care in patients with chronic type 2 Diabetes Mellitus. J Post Grad Med Inst; 21: 104-8.

8. Valk GD, Kriegsman DM, Assendelft WJ (2002): Patient education for preventing diabetic foot ulceration: A systemic review. Endocrinol Metab Clin North Am; 31: 633-58.

9. Rönnemaa T, Hämäläinen $H$, Toikka T, Liukkonen I (1997): Evaluation of the impact of podiatrist care in the primary prevention of foot problems in diabetic subjects. Diabetes Care; 20: 1833-7.

10. Viswanathan V, Madhavan S, Rajasekar S, Chamukuttan S, Ambady R 
(2005): Amputation prevention initiative in South India: positive impact of foot care education. Diabetes Care; 28: 101921.

11. American Diabetes Association (2003): Preventative foot care in people with diabetes. Diabetes Care 26(Suppl. 1):S78-S79. [PubMed]

12. American Diabetes Association: Comprehensive Foot Examination and Risk Assessment (2008): Diabetes Care ; 31(8): 1679-1685. Available at http://care.diabetesjournals.org/content/3 1/8/1679.

13. Desalu O, Salawu F, Jimoh A, Adekoya A, Busari O , Olokoba A(2011): Diabetic Foot Care: Self Reported Knowledge and Practice Among Patients Attending Three Tertiary Hospital in Nigeria. Ghana Med J; 45(2): 60-65.

14. Ogbera AO, Fasanmade O, Ohwovoriole AE, et al. (2006): An assessment of the disease burden of foot ulcers in patients with diabetes mellitus attending a teaching hospital in Lagos, Nigeria. Int J Low Extrem Wounds ;5:244-249 [PubMed]

15. Prompers L., Huijberts M., Apelquist J, et al. (2007): High prevalence of ischaemia, infection and serious comorbidity in patients with diabetic foot disease in Europe. Baseline results from the Eurodiale Study. Diabetologia; 50:1825 [PubMed].

16. Ren M, Yang C, Zhu Lin D, Xiao H, Mai L, Guo Y, Yan L (2014): Effect of Intensive Nursing Education on the Prevention of Diabetic Foot Ulceration Among Patients with High-Risk Diabetic Foot: A Follow-Up Analysis. Diabetes Technol Ther.; 16(9): 576-581.Available at

https://www.ncbi.nlm.nih.gov/pmc/articl es/PMC4135324/ .

17. Lutfi A, Zaraihah $\mathrm{M}$ and Ramdhan I (2014): Knowledge and Practice of Diabetic Foot Care in an In- Patient
Setting at a Tertiary Medical Center. Malays Orthop J; 8(3): 22-26.

18. Saeed N, Zafar J, Atta A (2010): Frequency of patients with diabetes taking proper foot care according to international guidelines and its impact on their foot health. J Pak Med Assoc. 2010 Sep; 60(9):732-5.

19. Hopkins N , Westergaard k (1998): Directions of change in Rural Egypt. American University in Cairo Press $p$ 223.

20. Cascio, E.U., and Lewis, E.G. (2006): Schooling and the Armed Forces Qualifying Test: Evidence from SchoolEntry Laws. Journal of Human Resources, XLI(2), pp. 294-318.

21. Bundorf, M.K., Wagner, T.H., Singer, S.J. and Baker, L.C. (2006): Who Searches the Internet for Health Information? Health Services Research, 41(3), Part I 819-836.

22. Wagner, T. H., Hu, T.-w., and Hibbard, J. H. (2001):The demand for consumer health information. Journal of Health Economics, 20(6), 1059-1075.

23. Neder S, Nadash P(2003): Individualized education can improve foot care for patients with diabetes. Home Healthc Nurse;21(12):837-40.

24. Chiwanga F and Njelekela M(2015): Diabetic foot: prevalence, knowledge, and foot self-care practices among diabetic patients in Dar EsSalaam, Tanzania - a cross-sectional study. Journal of Foot and Ankle Research ;8:20. DOI: 10.1186/s13047-015-0080-y. 25. Hasnain S1, Sheikh NH (2009): Knowledge and practices regarding foot care in diabetic patients visiting diabetic clinic in Jinnah Hospital, Lahore. J Pak Med Assoc ;59(10):687-90.

26. Yount KM, Agree EM (2004): The power of older women and men in Egyptian and Tunisian Families. J Marriage Fam; 66: 126-146.

27. Yount, K(2005):Women's family power and gender preference in Minya, Egypt. J Marriage Fam ; 67: 410-428. 
28. Saurabh S, Sarkar S, Selvaraj k, Sekhar Kar s, Kumar S, and Roy G (2014): Effectiveness of foot care education among people with type 2 diabetes in rural Puducherry, India. Indian J Endocrinol Metab ; 18(1): 106110. doi: $10.4103 / 2230-8210.126587$. 
Table (1): Frequency distribution of socio-demographic characteristics of the studied patients $(n=76)$

\begin{tabular}{|l|r|r|}
\hline Socio-demographic characteristics & \multicolumn{1}{|c|}{$\begin{array}{c}\text { No. } \\
(\mathbf{n = 7 6})\end{array}$} & $\%$ \\
\hline Age: & \multicolumn{2}{|c|}{ \% } \\
Range & \multicolumn{2}{|c|}{$26-70$} \\
Mean \pm SD & \multicolumn{2}{|c|}{$55.0 \pm 10.1$} \\
\hline Gender: & 20 & 26.3 \\
- Male & 56 & 73.7 \\
- Female & & \\
\hline Residence & 40 & 52.6 \\
Rural & 36 & 47.4 \\
Urban & & \\
\hline Education & 20 & 26.3 \\
- Illiterate & 4 & 5.3 \\
-read and write & 24 & 31.6 \\
- primary education & 16 & 21.1 \\
- Secondary & 12 & 15.7 \\
- higher education & & \\
\hline Occupation: & 44 & 57.9 \\
- Not working & 32 & 42.1 \\
- Working & & \\
\hline Income: & 24 & 31.6 \\
- Insufficient & 48 & 63.2 \\
- Sufficient & 4 & 5.2 \\
- Sufficient and saving & & \\
\hline
\end{tabular}


Table (2): Frequency distribution of diabetic history of the studied patients $(n=76)$

\begin{tabular}{|c|c|c|}
\hline History & $\begin{array}{c}\text { No. } \\
(\mathrm{N}=76)\end{array}$ & $\%$ \\
\hline $\begin{array}{l}\text { Type of diabetes: } \\
\text { - type } 1 \\
\text { - type } 2\end{array}$ & $\begin{array}{l}20 \\
56\end{array}$ & $\begin{array}{l}26.3 \\
73.7\end{array}$ \\
\hline $\begin{array}{l}\text { Duration (years) } \\
\text { Range } \\
\text { Median }\end{array}$ & \multicolumn{2}{|c|}{$\begin{array}{c}1-22 \\
10\end{array}$} \\
\hline $\begin{array}{l}\text { Treatment : } \\
\text {-Insulin } \\
\text {-Oral hypoglycemic } \\
\text { - Both }\end{array}$ & $\begin{array}{l}20 \\
44 \\
12 \\
\end{array}$ & $\begin{array}{l}26.3 \\
57.9 \\
15.8 \\
\end{array}$ \\
\hline $\begin{array}{l}\text { Foot ulcer } \\
\text {-Yes } \\
\text { Foot amputation } \\
\text {-Yes }\end{array}$ & 6 & $\begin{array}{l}7.0 \\
0.0\end{array}$ \\
\hline $\begin{array}{l}\text { Complication } \\
\text {-No } \\
\text {-Neurological } \\
\text {-eye complication }\end{array}$ & $\begin{array}{l}36 \\
28 \\
12\end{array}$ & $\begin{array}{l}47.4 \\
36.8 \\
15.8\end{array}$ \\
\hline $\begin{array}{l}\text { Comorbidity } \\
\text {-No } \\
\text {-Hypertension } \\
\text {-Cardiac } \\
\text {-Renal } \\
\text { - Liver }\end{array}$ & $\begin{array}{r}16 \\
28 \\
16 \\
4 \\
12\end{array}$ & $\begin{array}{r}21.1 \\
36.8 \\
21.1 \\
5.3 \\
15.7\end{array}$ \\
\hline $\begin{array}{l}\text { Regularly monitor blood glucose } \\
\text { (every month) }\end{array}$ & 48 & 63.2 \\
\hline Have advice to foot care & 28 & 36.8 \\
\hline Care of foot & 22 & 28.9 \\
\hline
\end{tabular}


Table (3): Risk classification of the studied group by International Working Group on the Diabetic Foot (IWGDF) - Risk Classification System

\begin{tabular}{|l|r|r|}
\hline & N=76 & \multicolumn{1}{|c|}{$\%$} \\
\hline 0-Normal - no neuropathy & 30 & 39.5 \\
\hline 1-Loss of protective sensation & 22 & 28.9 \\
\hline 2a-LOPS and deformity & 9 & 11.8 \\
\hline 2b-Peripheral arterial disease & 9 & 11.8 \\
\hline 3a-Previous history of ulceration & 6 & 7.9 \\
\hline 3b-Previous history of amputation & 0 & 0.0 \\
\hline
\end{tabular}


Table (4): Knowledge of the studied group before and after education intervention.

\begin{tabular}{|l|c|c|c|}
\hline Correct Answer & $\begin{array}{c}\text { Pre } \\
\text { intervention } \\
\text { \% }\end{array}$ & $\begin{array}{c}\text { Post } \\
\text { intervention } \\
\%\end{array}$ & $\begin{array}{c}\text { P } \\
\text { value* }\end{array}$ \\
\hline $\begin{array}{l}\text { 1-For prevention of diabetic foot we should control } \\
\text { blood sugar }\end{array}$ & $60(78.9)$ & $72(94.7)$ & $<0.001$ \\
\hline 2-For controlling blood sugar what must you do? & $40(52.6)$ & $64(84.2)$ & $<0.001$ \\
\hline 3-Why diabetic patients should care for their feet & $16(21.1)$ & $64(84.2)$ & $<0.001$ \\
\hline 4-How often you should inspect your feet & $32(42.1)$ & $76(100)$ & $<0.001$ \\
\hline 5-On inspection of your feet you should: & $24(31.6)$ & $72(94.7)$ & $<0.001$ \\
\hline 6-On washing your feet you should: & $12(15.8)$ & $60(78.9)$ & $<0.001$ \\
\hline 7-For dry skin you should: & $48(63.2)$ & $76(100)$ & $<0.001$ \\
\hline 8-For excessive sweating you should : & $44(57.9)$ & $67(88.1)$ & $<0.001$ \\
\hline 9-How to cut nails: & $8(10.5)$ & $68(89.5)$ & $<0.001$ \\
\hline 10-How to deal with toenails: & $28(36.8)$ & $72(94.7)$ & $<0.001$ \\
\hline 11-Type of socks should be worn : & $16(21.1)$ & $60(78.9)$ & $<0.001$ \\
\hline 12-On wearing socks you should: & $44(57.9)$ & $72(94.7)$ & $<0.001$ \\
\hline 13-How often you should inspect your shoes: & $52(68.4)$ & $72(94.7)$ & $<0.001$ \\
\hline 14-On using new shoes you should: & $16(21.1)$ & $52(68.4)$ & $<0.001$ \\
\hline 15-On sitting you should : & $32(42.1)$ & $68(89.5)$ & $<0.001$ \\
\hline 16-Symptoms of foot problem: & $32(42.1)$ & $68(89.5)$ & $<0.001$ \\
\hline 17-For improving circulation : & $32(42.1)$ & $72(94.7)$ & $<0.001$ \\
\hline $\begin{array}{l}\text { 18-In presence of redness or blood between toes } \\
\text { you should; }\end{array}$ & $56(73.7)$ & $72(94.7)$ & $<0.001$ \\
\hline $\begin{array}{l}\text { Total knowledge } \\
\text { Good } \\
\text { Mean } \pm \text { SD }\end{array}$ & $86(47.4)$ & $68(89.5)$ & $<0.001$ \\
\hline
\end{tabular}

*McNmar test, **Paired t 
Table (5): Foot self-care practice of the studied sample before and after intervention

\begin{tabular}{|c|c|c|c|}
\hline & $\begin{array}{c}\text { Pre intervention } \\
\text { No. }(\%)\end{array}$ & $\begin{array}{c}\text { Post intervention } \\
\text { No. }(\%)\end{array}$ & $\begin{array}{c}\mathbf{P} \\
\text { value* }^{*}\end{array}$ \\
\hline Inspect foot daily & $40(52.6)$ & $55(72.4)$ & 0.001 \\
\hline $\begin{array}{l}\text { Inspect Shoes Before Putting } \\
\text { Them On }\end{array}$ & $44(57.9)$ & $54(71.1)$ & 0.006 \\
\hline Wash Feet & $20(26.3)$ & $49(64.5)$ & 0.000 \\
\hline Dry Feet Well After Washing & $32(42.1)$ & $46(60.5)$ & 0.02 \\
\hline Use Emollients For Dry Skin & $36(47.4)$ & $49(65.5)$ & 0.002 \\
\hline Cut Toenails Properly & $44(57.9)$ & $58(76.3)$ & 0.003 \\
\hline Walk Bare Foot & $24(31.6)$ & $41(53.9)$ & $<0.001$ \\
\hline Wear Shoes Without Socks & $20(26.3)$ & $35(46.1)$ & 0.004 \\
\hline Check Between Toe & $48(63.2)$ & $63(82.9)$ & 0.008 \\
\hline Dry Between The Toes & $36(47.4)$ & $49(64.5)$ & 0.06 \\
\hline $\begin{array}{llc}\text { Check } & \text { of } & \text { Water } \\
\text { Temperature Before } & \text { Bath } \\
\end{array}$ & $28(36.8)$ & $47(61.8)$ & 0.001 \\
\hline $\begin{array}{l}\text { Seek Professional Help For } \\
\text { any Problem }\end{array}$ & $12(15.8)$ & $37(48.7)$ & $<0.001$ \\
\hline $\begin{array}{l}\text { Total practice } \\
\text { Good } \\
\text { Median } \\
\text { Range }\end{array}$ & $\begin{array}{c}28(36.8) \\
5 \\
1-11\end{array}$ & $\begin{array}{c}69(90.8) \\
8 \\
4-11\end{array}$ & $<0.001$ \\
\hline
\end{tabular}

*McNemar test used, ** Wilcoxon Signed Rank Test 
Table (6): Impact of demographic factors on the baseline knowledge and practice of participants

\begin{tabular}{|c|c|c|c|c|c|c|}
\hline & $\begin{array}{c}\text { Good } \\
\text { Knowledge } \\
(\mathrm{N}=36)(\%) \\
\end{array}$ & $\begin{array}{c}\text { Poor } \\
\text { Knowledge } \\
(\mathrm{N}=40)(\%) \\
\end{array}$ & $\begin{array}{c}\mathbf{P} \\
\text { value }\end{array}$ & $\begin{array}{c}\text { Good } \\
\text { practice } \\
(\mathrm{N}=28) \\
\end{array}$ & $\begin{array}{c}\text { Poor } \\
\text { Practice } \\
(\mathrm{N}=48) \\
\end{array}$ & $\begin{array}{c}\mathbf{P} \\
\text { value* }^{*}\end{array}$ \\
\hline $\begin{array}{l}\text { Sex } \\
\text {-Male } \quad(20) \\
\text {-female }(56)\end{array}$ & $\begin{array}{l}16(80.0) \\
20(35.7)\end{array}$ & $\begin{array}{r}4(20.0) \\
36(64.3)\end{array}$ & 0.001 & $\begin{array}{c}0(0.0) \\
28(50)\end{array}$ & $\begin{array}{r}20(100.0) \\
28(50.0)\end{array}$ & 0.00 \\
\hline $\begin{array}{l}\text { Residence } \\
\text { Rural ( 40) } \\
\text { Urban (36) }\end{array}$ & $\begin{array}{l}12(30.0) \\
24(66.7)\end{array}$ & $\begin{array}{l}28(70.0) \\
12(33.3)\end{array}$ & 0.001 & $\begin{array}{r}8(20.0) \\
20(55.6)\end{array}$ & $\begin{array}{r}32(80.0) \\
16(44.4)\end{array}$ & 0.001 \\
\hline $\begin{array}{l}\text { Education } \\
\text { Elementary(48) } \\
\text { Secondary (16) } \\
\text { High (12) }\end{array}$ & $\begin{array}{r}15(31.3) \\
12(75.0) \\
9(75.0)\end{array}$ & $\begin{array}{l}33(68.7) \\
4(25.0) \\
3(25.0)\end{array}$ & 0.001 & $\begin{array}{cc}16 & (33.3) \\
8 & (50.0) \\
4 & (33.3)\end{array}$ & $\begin{array}{l}32(66.6) \\
8(50.0) \\
8(66.7)\end{array}$ & 0.47 \\
\hline $\begin{array}{l}\text { Occupation } \\
\text { Not working (44) } \\
\text { Working } \quad(32)\end{array}$ & $\begin{array}{l}20(45.5) \\
16(50.0) \\
\end{array}$ & $\begin{array}{l}24(54.5) \\
16(50.0) \\
\end{array}$ & 0.69 & $\begin{array}{l}16(36.4) \\
12(37.5) \\
\end{array}$ & $\begin{array}{l}28(63.6) \\
20(62.5)\end{array}$ & 0.92 \\
\hline
\end{tabular}

*Chi-square test 